\title{
SEASONAL VARIATIONS OF GASEOUS EMISSIONS FROM A NATURALLY VENTILATED DAIRY BARN QUANTIFIED USING TRACER GAS TECHNIQUE
}

\author{
M. Samer ${ }^{1,2}$
}

\section{ABSTRACT}

Twenty nine field experiments were carried out to study the ventilation rate in a naturally ventilated dairy barn during 4 summer seasons and 3 winter seasons. The air exchange rates (AER) were determined by the tracer gas technique (TGT), which was the decay of the radioactive tracer gas Krypton-85, and the $\mathrm{CO}_{2}$-balance was set as reference method (RM). During each field experiment, continuous measurements of the gaseous concentrations $\left(\mathrm{NH}_{3}, \mathrm{CO}_{2}, \mathrm{CH}_{4}\right.$, and $\left.\mathrm{N}_{2} \mathrm{O}\right)$ inside and outside the building and ${ }^{85} \mathrm{Kr}$ tracer gas experiments inside the building were carried out. The TGT was further developed by working on the gas release location and the calculation method. However, the TGT still overestimating the AER by $1.63 \pm 0.14$ fold the $R M$ in summer $\left(R^{2}=0.94\right)$ and $1.19 \pm 0.15$ fold the $R M$ in winter $\left(R^{2}=0.91\right)$. The tracer gas technique is a promising method; however, it overestimates the AER. On the other hand, the $\mathrm{CO}_{2}$-balance has several error sources that depend on animal production of $\mathrm{CO}_{2}$ which varies in function of animal weight, productivity and pregnancy. Therefore, the tracer gas technique should be further developed, where it delivers comparable results and is independent on the physiological changes. The average gaseous emissions through summer seasons, subject to the reference method, were 124, 538, 45610, and $28 \mathrm{~g} \mathrm{~d}^{-1} \mathrm{AU}^{-1}$ for $\mathrm{NH}_{3}, \mathrm{CH}_{4}, \mathrm{CO}_{2}$, and $\mathrm{N}_{2} \mathrm{O}$ respectively. On the other hand, they were average of 64, 348, 42760, and $39 \mathrm{~g} \mathrm{~d}^{-1} A U^{-1}$ through winter seasons.

\section{Keywords}

Tracer Gas Technique, $\mathrm{CO}_{2}$-Balance, Ventilation Rate, Air Exchange Rate, Natural Ventilation, Gaseous Emissions, Animal Building.

\footnotetext{
${ }^{1}$ Assistant Professor, Department of Agricultural Engineering, Faculty of Agriculture, Cairo University, Egypt

${ }^{2}$ Research Scientist, Leibniz Institute for Agricultural Engineering Potsdam-Bornim (ATB), Potsdam, Germany
} 


\section{INTRODUCTION}

bout $94 \%$ of global anthropogenic emissions of $\mathrm{NH}_{3}$ to the
atmosphere originate from the agricultural sector of which close
to $64 \%$ is associated with livestock management (FAO, 2006). Excessive levels of $\mathrm{NH}_{3}$ emissions contribute to eutrophication and acidification (Schuurkes and Mosello, 1988). Enteric fermentation and manure management account for 35-40\% of the total anthropogenic $\mathrm{CH}_{4}$ emissions and $80 \%$ of $\mathrm{CH}_{4}$ release from agriculture. Livestock activities contribute with $65 \%$ of the global anthropogenic $\mathrm{N}_{2} \mathrm{O}$ emissions and account for $75-80 \%$ of the emission from agriculture (FAO, 2006). $\mathrm{CH}_{4}$ and $\mathrm{N}_{2} \mathrm{O}$ are greenhouse gases $(\mathrm{GHG})$ with global warming potentials of 23 and 296 times that of $\mathrm{CO}_{2}$, respectively (IPCC, 2007).

Therefore, reducing the emissions is a demand. One key issue is to quantify gaseous emissions from livestock buildings. Unfortunately, the quantification of the gaseous emissions from naturally ventilated animal houses is complicated and shows large uncertainties; particularly the determination of ventilation rates. Therefore, the implemented methods to determine the ventilation rate should be improved and further developed (Lung et al., 2002; Müller and Möller, 1998; Schneider et al., 2005).

In order to determine the ventilation rate, many approaches are available such as tracer gas technique. The tracer gas may be radioactive krypton85 , or sulfur hexafluoride $\mathrm{SF}_{6}$. Tracer gases are used for a wide variety of detection techniques including atmospheric tracing and leak detection. Additionally, the tracer gas technique is one of the implemented approaches for quantifying ventilation rates through naturally ventilated barns which is used for estimating infiltration, air exchange measurements, and spreading of pollutants (Müller and Möller, 1998; Snell et al., 2003).

Xin et al. (2009) stated that the $\mathrm{CO}_{2}$-balance or concentration difference method offers a viable alternative or supplemental check for quantifying building ventilation rate under certain conditions where direct, continuous ventilation rate measurement is not feasible.

This paper aims at evaluating, developing, and comparing the different factor combinations specifying the best factors combination of the tracer gas method, i.e. decay of the radioactive tracer Krypton-85, for summer 
and winter measurements of air exchange rate. Where, the $\mathrm{CO}_{2}$-balance was set as the reference method. The paper aims further at investigating the seasonal variations of gaseous emissions from a naturally ventilated dairy barn.

\section{MATERIALS AND METHODS \\ Specifications of the Barn}

The measurements were carried out during 4 summer seasons and 3 winter seasons, in a naturally ventilated dairy barn located in north-east Germany (at latitude of $54^{\circ} 1^{\prime} 0^{\prime \prime} \mathrm{N}$, longitude of $12^{\circ} 13^{\prime} 60^{\prime \prime} \mathrm{E}$, and altitude of $43 \mathrm{~m}$ ). The investigated dairy barn is surrounded by several agricultural buildings, except the southern and western sides. Fortunately, the prevailing summer winds are south and south-west winds. The dairy barn was $96.15 \mathrm{~m}$ long and $34.2 \mathrm{~m}$ wide. The roof top varied from $4.2 \mathrm{~m}$ at the side to $10.73 \mathrm{~m}$ at the gable top. The internal room volume of the barn amounted to $25,499 \mathrm{~m}^{3}\left(70 \mathrm{~m}^{3} \mathrm{cow}^{-1}\right)$, where the barn is designed to accommodate 364 dairy cows in loose housing system with freestalls. The manure handling system was equipped with winch-drawn dung channel scrapper. The dairy barn was naturally ventilated by air draft introduced into the building through adjustable curtains in the sidewalls (which were protected by nets and open in summer but closed in winter), open ridge slot, space boards of the gable walls, and open doors in the gable walls. During the summer season, three additional ceiling fans were used to enhance the uniformity of air distribution inside the barn. The fans were mounted to the ceiling along the building centreline and had a diameter of $7.2 \mathrm{~m}$ with a maximum discharge of $546,000 \mathrm{~m}^{3} \mathrm{~h}^{-1}$.

\section{Experimental Procedures}

The measurements were conducted over 2-week period per season, where the air temperature and humidity were measured inside and outside the building using 6 temperature-humidity sensors/loggers (TFL), and the wind velocity was measured and recorded by a weather station. Furthermore, the concentrations of $\mathrm{CO}_{2}, \mathrm{NH}_{3}, \mathrm{CH}_{4}$, and $\mathrm{N}_{2} \mathrm{O}$ were continuously measured, using a multi-gas monitor (INNOVA 1312, Innova AirTech Instruments, Ballerup, Denmark), inside the barn at eight uniformly distributed sampling points (MP) and outside the barn at four 
points (Figs. 1 and 2). Within the aforementioned periods, ventilation measurements were carried out with the tracer radioactive isotope Krypton-85, between five and six times per campaign, i.e. per investigation period. The tracer gas was released inside the building in order to determine the air exchange rate using the decay method, where ideal mixing of both air and tracer gas inside the building was assumed. The decrease of radioactive impulses was measured for each release using 20 radiation counters $(Z)$. The air exchange rate is then the result of an exponential relation between the impulses and the time. The tracer gas continuous releases varied in location: (1) a line in the middle of the building over the feeding bunk (orange line), (2) a line in the windward side of the building over the manure alley (orange line), and (3) fixedpoint source (orange oval). The calculation procedures were compared and they are: (1) average $\alpha$-values ( $\alpha$ is the AER per second calculated for one radiation counter) of selected radiation counters, (2) average $\alpha$-values of all radiation counters, (3) sum impulses of selected radiation counters, and (4) sum impulses of all radiation counters for all release locations. The emission mass flow from the livestock building was calculated as the product of both the concentration difference between emitted and fresh air and the airflow rate. The results were compared with each other by performing Pearson correlation analyses and developing linear regression models. The differences between the reference method and the factor combinations were tested using the ANOVA model. The statistical analysis was carried out using SAS v.9.2 (SAS Institute, Cary, USA).

\section{Tracer Gas Technique}

The trace gas under consideration was Krypton-85, where the decay of radioactive isotope ${ }^{85} \mathrm{Kr}$ was implemented. The tracer gas was distributed four to five times each summer and winter season. Fourteen gas experiments were carried out in summer and fifteen experiments in winter, i.e. a sum of 29 tracer gas experiments. The tracer gas was released inside the building and ideal mixing of both the air and tracer gas inside the building was assumed. The duration of each tracer gas measurement was 15 min including the release, decay, and idle time. During the two week periods when the gaseous concentration was 
measured, temperature and relative humidity were continuously measured. The tracer gas experiments were conducted in the middle of the 2-week period of each set of measurements. Tracer gas was constantly released during each investigation and the decrease of impulses was measured for each release. Uncertainties with this method can be caused by inadequate mixing of the tracer gas in the air plenum of the building. The ventilation rate was calculated using the decay method of radioactive ${ }^{85} \mathrm{Kr}$ as follows:

$$
\begin{aligned}
& I=I_{0} \cdot e^{-\alpha \cdot t} \\
& \dot{V}_{T G T}=\alpha \cdot v
\end{aligned}
$$

Equation (1) is an exponential function, where $I$ represents the impulses recorded by the radiation counters per second, $t$ is the time in seconds, $\alpha$ $\left(\mathrm{s}^{-1}\right)$ represents the air exchange rate per second, and $I_{0}$ is the impulses at $\mathrm{t}=0$. The term $\alpha\left(\mathrm{s}^{-1}\right)$ should be converted to air exchange rate per hour in order to be used in Eq. (2) where, $v\left(\mathrm{~m}^{3}\right)$ is the volume of the building, and $\dot{V}_{T G T}\left(\mathrm{~m}^{3} \mathrm{~h}^{-1}\right)$ represents the ventilation rate estimated using the tracer gas technique. Calculation procedure was sum impulses of all radiation counters.

\section{$\mathrm{CO}_{2}$-Balance}

Carbon dioxide $\left(\mathrm{CO}_{2}\right)$, formed by animal respiration, can be used as a natural tracer gas. The ventilation rate throughout the building can be determined by calculating the mass balance of $\mathrm{CO}_{2}$ flow. Equation (3) explains the relationship between the ventilation rate and the gas production rate assuming ideal mixing with the air inside the building:

$$
\dot{V}_{\mathrm{CO}_{2}}=\frac{P_{\mathrm{CO}_{2}} \cdot N_{\mathrm{C}}}{\mathrm{C}_{i}-\mathrm{C}_{o}}
$$

Where, $P_{\mathrm{CO}_{2}}\left(\mathrm{mg} \mathrm{h}^{-1} \mathrm{cow}^{-1}\right)$ represents the production rate of $\mathrm{CO}_{2}$ from one cow, $\mathrm{N}_{\mathrm{C}}$ is the number of cows housed inside the barn, $\dot{V}_{\mathrm{CO}_{2}}\left(\mathrm{~m}^{3} \mathrm{~h}^{-1}\right)$ is the ventilation rate calculated according to the $\mathrm{CO}_{2}$-balance, and $C_{i}(\mathrm{mg}$ $\left.\mathrm{m}^{-3}\right)$ and $C_{o}\left(\mathrm{mg} \mathrm{m}^{-3}\right)$ are the concentrations of the gas inside and outside the barn, respectively. However, the gas concentration inside the barn is not the same throughout the building and changes with time, therefore 
equation (3) is an approximate estimating for gas production in dairy barns. This method was considered as the reference method in this study for the statistical anlysis issues. Within the $\mathrm{CO}_{2}$-balance, $\mathrm{CO}_{2}$ production $\left(\mathrm{g} \mathrm{h}^{-1}\right)$ is calculated according to heat and $\mathrm{CO}_{2}$ production mathematical models. Thus, the estimated volumetric flow rate depends on the accuracy of $\mathrm{CO}_{2}$ production model in addition to other factors, e.g. weather conditions. Most of $\mathrm{CO}_{2}$ is formed by the animals and exhaled by respiration. It can also be part of exhaust gases of heating systems being released in the barns, which is not the case of the investigated barn. Additionally, a certain portion of $\mathrm{CO}_{2}$ is released by the manure. Concerning the uncertainties in measuring $\mathrm{CO}_{2}$ concentrations and then the ventilation rates, $\mathrm{CO}_{2}$ production from the urine and dung has mostly been neglected in the mass balance models.

\section{RESULTS AND DISCUSSION}

Through summer seasons, the temperature outside the barn ranged between $14.5{ }^{\circ} \mathrm{C}$ and $29.3{ }^{\circ} \mathrm{C}$ during the investigations. The temperature inside the building ranged between $15.3{ }^{\circ} \mathrm{C}$ and $31.4{ }^{\circ} \mathrm{C}$ during all investigations periods. The wind velocity (direction and speed) largely fluctuated, where the wind direction ranged between $116^{\circ}$ and $359^{\circ}$ from north and the wind speed varied from 0.4 to $3.64 \mathrm{~m} \mathrm{~s}^{-1}$ during the experiments. But through winter seasons, the temperature outside the barn ranged between $-7.6{ }^{\circ} \mathrm{C}$ and $10.1{ }^{\circ} \mathrm{C}$. The temperature inside the building ranged between $-4.7{ }^{\circ} \mathrm{C}$ and $11.3{ }^{\circ} \mathrm{C}$. Similar to summer, the wind velocity largely fluctuated where the direction ranged between $142^{\circ}$ and $352^{\circ}$ from north and the speed varied from 1.16 to $4.68 \mathrm{~m} \mathrm{~s}^{-1}$ during the experiments.

The best factor combinations, having the highest $\mathrm{R}^{2}$ values and the most reliable parameter estimates, were: (1) release over feeding bunk considering the impulses recorded by all of the radiation counters and implementing the sum method $\left(\mathrm{R}^{2}=0.94 ; 1.63 \pm 0.14\right)$ for summer seasons, and (2) point release source considering the impulses recorded by all radiation counters and implementing the sum method $\left(\mathrm{R}^{2}=0.91\right.$; $1.19 \pm 0.15$ ) for winter seasons. 


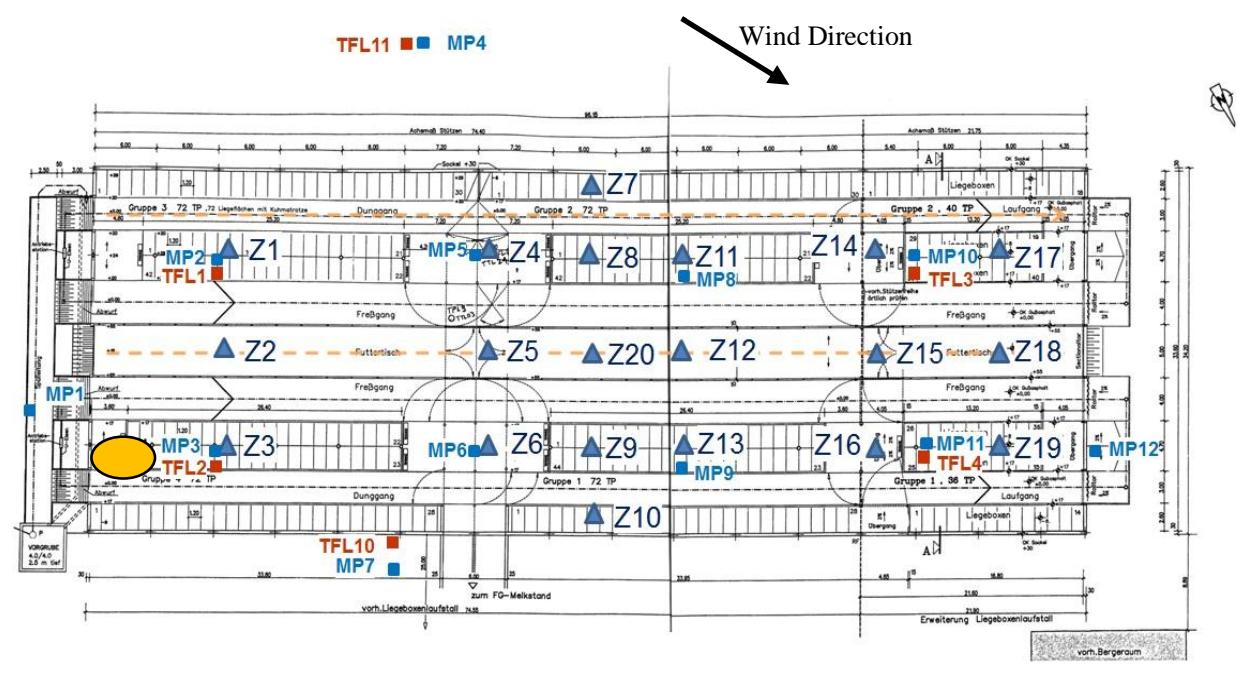

Figure 1: Plan view of the investigated barn.

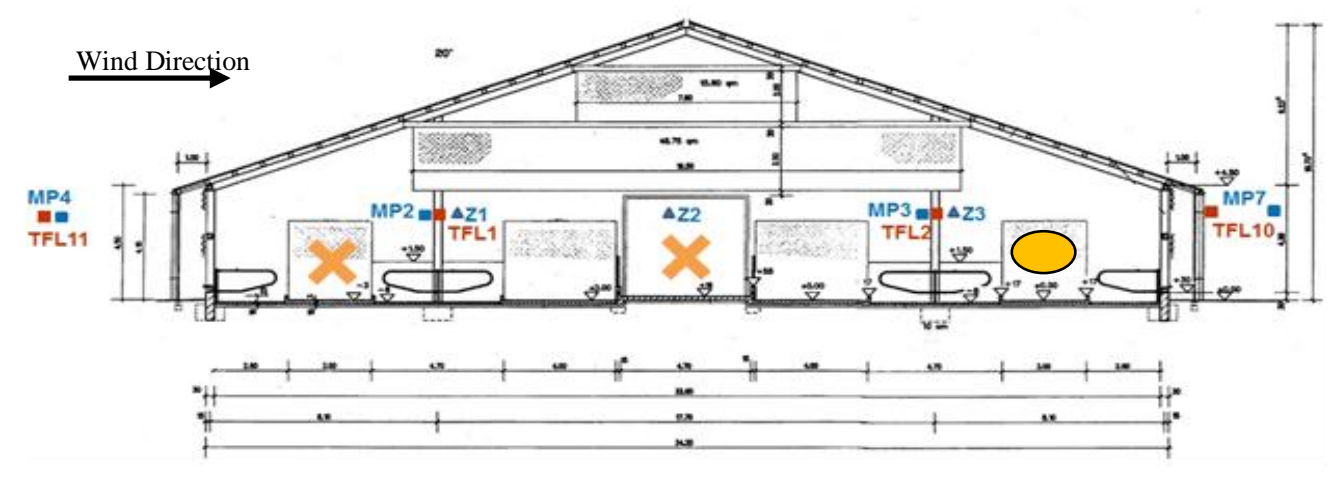

Figure 2: Side view of the investigated dairy barn. 
The average gaseous emissions through summer seasons, by the reference method were 124, 538, 45610, and $28 \mathrm{~g} \mathrm{~d}^{-1} \mathrm{AU}^{-1}$ for $\mathrm{NH}_{3}, \mathrm{CH}_{4}$, $\mathrm{CO}_{2}$, and $\mathrm{N}_{2} \mathrm{O}$ respectively. On the other hand, they were average of 64 , 348, 42760, and $39 \mathrm{~g} \mathrm{~d}^{-1} \mathrm{AU}^{-1}$ through winter seasons. The emissions factors, subject to the reference method, were 34.4, 161.7, 16127, and 123 $\mathrm{kg} \mathrm{yr}^{-1} \mathrm{AU}^{-1}$ for $\mathrm{NH}_{3}, \mathrm{CH}_{4}, \mathrm{CO}_{2}$, and $\mathrm{N}_{2} \mathrm{O}$ respectively. They were calculated as average of the summer and winter values.

The $\mathrm{CO}_{2}$-balance was set as the reference method in our study owing to the statements of Xin et al. (2009) and Madsen et al. (2010) who emphasised that the $\mathrm{CO}_{2}$-balance is a reliable, accurate, simple, fast, and cheap method to estimate the ventilation rates and the gaseous emissions from animal housing. The calculations of $\mathrm{CO}_{2}$ excretion rate $\left(\mathrm{g} \mathrm{h}^{-1} \mathrm{cow}^{-1}\right)$ were performed using heat and $\mathrm{CO}_{2}$ production mathematical model. The calculations took into consideration the required energy for milk yield, the required energy for pregnancy, and the heat production for life maintenance where the average mass of the animals was considered. These procedures agree with Pedersen et al. (2008) and Madsen et al. (2010).

Table 1: Air exchange rates and gaseous emissions by both methods through 4 summer seasons

\begin{tabular}{|c|c|c|c|c|c|c|c|c|c|c|}
\hline \multirow[t]{2}{*}{ Experiment } & \multicolumn{2}{|c|}{ AER } & \multicolumn{2}{|c|}{$\begin{array}{c}\mathrm{NH}_{3} \\
\mathrm{~g} \mathrm{~d}^{-1} A U^{-1}\end{array}$} & \multicolumn{2}{|c|}{$\underset{\mathrm{g} \mathrm{d}^{-1} \mathbf{A U}^{-1}}{\mathbf{C H}_{4}}$} & \multicolumn{2}{|c|}{$\begin{array}{c}\mathrm{CO}_{2} \\
\mathrm{~g} \mathrm{~d}^{-1} \mathbf{A U}^{-1}\end{array}$} & \multicolumn{2}{|c|}{$\begin{array}{c}\mathrm{N}_{2} \mathrm{O} \\
\mathrm{g} \mathrm{d}^{-1} \mathbf{A U}^{-1}\end{array}$} \\
\hline & TGT & RM & TGT & $\mathbf{R M}$ & TGT & $\mathbf{R M}$ & TGT & RM & TGT & $\mathbf{R M}$ \\
\hline 1 & 64 & 90 & 342 & 481 & 1104 & 1552 & 82684 & 116275 & 55 & 77 \\
\hline 2 & 42 & 23 & 218 & 120 & 625 & 342 & 50696 & 27762 & 37 & 20 \\
\hline 3 & 185 & 41 & 537 & 119 & 2418 & 536 & 201345 & 44622 & 137 & 30 \\
\hline 4 & 61 & 51 & 117 & 98 & 665 & 556 & 63819 & 53357 & 46 & 38 \\
\hline 5 & 79 & 59 & 224 & 167 & 865 & 646 & 80579 & 60179 & 63 & 47 \\
\hline 6 & 25 & 30 & 61 & 73 & 355 & 427 & 28326 & 33992 & 14 & 17 \\
\hline 7 & 27 & 18 & 103 & 68 & 557 & 371 & 35262 & 23509 & 16 & 10 \\
\hline 8 & 106 & 53 & 295 & 148 & 1605 & 803 & 136843 & 68421 & 71 & 36 \\
\hline 9 & 51 & 26 & 168 & 86 & 922 & 470 & 66392 & 33847 & 35 & 18 \\
\hline 10 & 76 & 36 & 247 & 117 & 1068 & 506 & 89184 & 42245 & 52 & 25 \\
\hline 11 & 97 & 49 & 128 & 65 & 685 & 346 & 100790 & 50914 & 67 & 34 \\
\hline 12 & 29 & 27 & 70 & 65 & 355 & 330 & 34601 & 32215 & 20 & 18 \\
\hline 13 & 20 & 19 & 66 & 63 & 323 & 307 & 26490 & 25166 & 13 & 12 \\
\hline 14 & 18 & 20 & 64 & 71 & 307 & 341 & 23429 & 26033 & 12 & 13 \\
\hline Average & 63 & 39 & 189 & 124 & 847 & 538 & 72889 & 45610 & 46 & 28 \\
\hline
\end{tabular}


Table 2: Air exchange rates and gaseous emissions by both methods through 3 winter seasons

\begin{tabular}{|c|c|c|c|c|c|c|c|c|c|c|}
\hline \multirow[t]{2}{*}{ Experiment } & \multicolumn{2}{|c|}{ AER } & \multicolumn{2}{|c|}{ 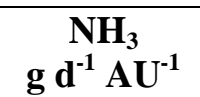 } & \multicolumn{2}{|c|}{$\underset{\mathrm{g} \mathrm{d}^{-1} \mathbf{A} \mathbf{A U}_{4}}{\mathbf{C u}^{-1}}$} & \multicolumn{2}{|c|}{ 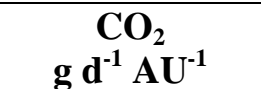 } & \multicolumn{2}{|c|}{$\begin{array}{c}\mathbf{N}_{2} \mathbf{O} \\
\mathrm{g} \mathrm{d}^{-1} \mathbf{A} \mathbf{U}^{-1}\end{array}$} \\
\hline & TGT & $\mathbf{R M}$ & TGT & $\mathbf{R M}$ & TGT & $\mathbf{R M}$ & TGT & $\mathbf{R M}$ & TGT & $\mathbf{R M}$ \\
\hline 1 & 39 & 33 & 59 & 50 & 432 & 363 & 51694 & 43440 & 53 & 45 \\
\hline 2 & 37 & 31 & 56 & 47 & 450 & 378 & 49523 & 41616 & 51 & 42 \\
\hline 3 & 31 & 26 & 47 & 39 & 374 & 314 & 43897 & 36888 & 42 & 36 \\
\hline 4 & 45 & 38 & 63 & 53 & 416 & 350 & 57207 & 48072 & 62 & 52 \\
\hline 5 & 39 & 33 & 51 & 43 & 328 & 276 & 51265 & 43080 & 53 & 45 \\
\hline 6 & 18 & 15 & 43 & 36 & 418 & 351 & 30816 & 25896 & 21 & 18 \\
\hline 7 & 14 & 12 & 35 & 29 & 352 & 295 & 26304 & 22104 & 17 & 15 \\
\hline 8 & 17 & 14 & 50 & 42 & 399 & 335 & 30274 & 25440 & 20 & 17 \\
\hline 9 & 20 & 17 & 47 & 40 & 346 & 291 & 32558 & 27360 & 27 & 22 \\
\hline 10 & 17 & 14 & 41 & 35 & 337 & 283 & 29702 & 24960 & 23 & 19 \\
\hline 11 & 61 & 51 & 153 & 128 & 465 & 390 & 77483 & 65112 & 72 & 60 \\
\hline 12 & 55 & 46 & 121 & 102 & 414 & 348 & 69429 & 58344 & 65 & 54 \\
\hline 13 & 88 & 74 & 206 & 173 & 741 & 623 & 110956 & 93240 & 101 & 84 \\
\hline 14 & 41 & 35 & 48 & 40 & 369 & 306 & 53521 & 44976 & 48 & 40 \\
\hline 15 & 38 & 32 & 126 & 106 & 377 & 317 & 48638 & 40872 & 44 & 37 \\
\hline Average & 37 & 31 & 76 & 64 & 415 & 348 & 50884 & 42760 & 47 & 39 \\
\hline
\end{tabular}

The constant release tracer gas method was implemented in our study owing to the findings of Demmers et al. (2001) who found that the constant release tracer gas method give the most reliable estimates of ventilation rate. Additionally, the evenly dosing of ${ }^{85} \mathrm{Kr}$ was in a line over the southern manure alley and compared to the release over the feeding line and the fixed-point source. Where, the southern manure alley was selected because it faces the prevailing winds, which blows from the south and south-west, and is near to the southern side where the air intrudes into the building allowing better ${ }^{85} \mathrm{Kr}$ mixing with air and then better distribution throughout the whole building. This was confirmed by the observation of the radiation counters where all of the 20 radiation counters detected the tracer gas when it was released over the manure alley in comparison to a maximum of 15 radiation counters detected the tracer gas when released over the feeding bunk, and 10 radiation counters when the tracer was released from a fixed point. This concept agrees with that developed by Snell et al. (2003). The results of our study show that the ${ }^{85} \mathrm{Kr}$ tracer gas technique overestimates the air exchange rate by about 1.63 and 1.19 fold the air exchange rate estimated by the $\mathrm{CO}_{2}$-balance 
through summer and winter seasons, respectively. This overestimation can be attributed to the fact that there are airflows between the different zones inside the building Sherman (1989). In other words, the tracer gas flows from one zone to another within the building and is then detected by several radiation counters leading to multi-detection of the same dosing of tracer gas and then overestimating the real air exchange rate between the building and the outside. Furthermore, the overestimation by tracer gas technique is also related to the permeation rate (PR), where using a narrow range in PR and balancing of PR between treatments should be practised Pinares-Patino and Clark (2008). This statement was considered in our study whereas all ${ }^{85} \mathrm{Kr}$ experiments were performed using a fixed quantity, $2 \mathrm{GBq}$ per experiment. However, the PR is not only depending on dosing of tracer gas, but also on the airflow patterns inside the barn which varies in function of time and location, and further the occupancy of the barn. Therefore, the balancing of PR between treatments is hardly achievable in naturally ventilated buildings.

The gaseous concentrations varied in function of time of measurement and location of the sampling point inside the barn. Therefore, the measurements were carried out during 2 weeks whereas eight sampling points were symmetrically distributed inside the barn to cover the whole area of the barn (Fig. 1). Both concept and procedure agree with those stated and performed by Ngwabie et al. (2009).

Using the reference method, the gaseous emissions were calculated. Moreover, the emission factors were calculated as average of the winter and summer measurements to be representative for the whole year. Nevertheless, due to different climate and microclimate conditions in spring, autumn, summer and winter actual yearly emission factors might vary. According to our study, the average $\mathrm{NH}_{3}$ emission factor was 44.6

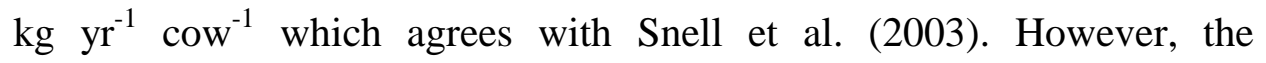
guidelines of the "Technical Instructions on Air Quality Control - TA Luft" (TA-Luft, 2002) in Germany specified the constant emission factor $\mathrm{e}_{\mathrm{NH} 3}$ as $15.79 \mathrm{~kg} \mathrm{yr}^{-1}$ for one freestall which is one third the value measured in our study. On the other hand, Adviento-Borbe et al. (2010) mentioned that the highest average ammonia emission coincided with higher environmental temperature at $32{ }^{\circ} \mathrm{C}$ and was $30 \mathrm{~g} \mathrm{~d}^{-1} \mathrm{AU}^{-1}$. 
Nonetheless, the average ammonia emission according to our study and subject to the reference method was average of $124 \mathrm{~g} \mathrm{~d}^{-1} \mathrm{AU}^{-1}$ for the considered summer seasons suggesting that our aforementioned value is too high, where low emission values can only be achieved by reducing the emission source surfaces, decreasing temperature and air velocity near the source, and minimizing air volumetric flow rates throughout the livestock buildings (Bjorneberg, et al. 2009). This elucidates the conflict between the demand of animal welfare and low emissions. With new technical solutions a compromise between animal welfare and low emissions should be found. On the other side, Ngwabie et al. (2009) carried out winter measurements where the ventilation rate was calculated by $\mathrm{CO}_{2}$ mass balance and the emission of $\mathrm{NH}_{3}$ was subsequently determined. They found that $\mathrm{NH}_{3}$ emission was in the range of $0.89-1.13 \mathrm{~g} \mathrm{~h}^{-1} \mathrm{AU}^{-1}$. In contrast, the $\mathrm{NH}_{3}$ emission was $3.9 \mathrm{~g} \mathrm{~h}^{-1} \mathrm{AU}^{-1}$ in our study. This can be attributed to the fact that higher ventilation rates were recorded in our study as well as the floor type and the airflow patterns are different to their study.

It has been noticed that the emission mass flow rate, specific emission mass flow rate, and especially the gas concentration of the gases $\left(\mathrm{NH}_{3}\right.$, $\mathrm{CH}_{4}$ and $\mathrm{CO}_{2}$ ) were higher through summer seasons and lower through winter seasons except for $\mathrm{N}_{2} \mathrm{O}$ which has lower gaseous emissions through summer seasons but higher through winter seasons (Tables 1 and 2). This event occurs owing to the available nitrogen in the manure and the contaminate surface areas is transformed through nitrification and denitrification processes to $\mathrm{N}_{2} \mathrm{O}$, considering that the cows were fed with almost the same mixed ration of forages through winter and summer seasons. The optimal temperatures range for nitrification is $30-35{ }^{\circ} \mathrm{C}$ which did not occur through summer seasons. In contrast, the optimal temperature for denitrification is $10{ }^{\circ} \mathrm{C}$ or lower which occurred often through winter seasons and this explains the high $\mathrm{N}_{2} \mathrm{O}$ concentrations and emissions through winter seasons compared to summer seasons (Reinhardt-Hanisch, 2008; Giltrap et al., 2010). On the other hand, the concentrations and the emissions of the gases $\mathrm{NH}_{3}, \mathrm{CH}_{4}$ and $\mathrm{CO}_{2}$ were higher in summer (higher temperatures) than in winter (lower temperatures) which agrees with Pereira et al. (2011) who stated that in 
naturally ventilated cattle buildings, the gaseous emissions significantly increase with air temperature $\left(5-25{ }^{\circ} \mathrm{C}\right)$. The differences between the emission rates in summer to winter can be further explained by statements of Bjorneberg et al. (2009) who stated that low emission values can only be achieved by decreasing air velocity and temperature near the emission source, and minimizing air volumetric flow rates throughout the livestock buildings, where in winter the airflow rates were lower than in summer.

\section{CONCLUSIONS}

It can be conclude that the sum of impulses leads to better results than the average impulses. Where, considering all the readings of the radiation counters is more representative for air movement and easier to calculate the air exchange rate. In summer, the release of tracer gas over the southern manure alley showed a better detection by all radiation counters emphasizing a better mixing of tracer gas with air and a better distribution of this mixture inside the barn, owing to the fact that the southern side of the building is totally open through summer seasons and the prevailing summer wind is south to south-west which led to better mixing of tracer gas with air and better distribution of air inside the building. In winter, the from a source point showed better results than the other methods, due to the fact that the building is totally closed in winter seasons. The tracer gas technique is a promising method; however, it overestimates the air exchange rate. On the other hand, the $\mathrm{CO}_{2}$-balance has several error sources that may have negative influences on the determination of ventilation rates, such as: (1) calculations of metabolic energy, (2) $\mathrm{CO}_{2}$ produced per energy unit, (3) amount of $\mathrm{CO}_{2}$ emitted from manure, (4) location of $\mathrm{CO}_{2}$ sampling points, and (5) animal data (weigh, productivity and pregnancy). Therefore, the tracer gas technique should be further developed, where it delivers comparable results and is independent on the physiological changes. Developing the TGT should focus on the release location and the calculation method.

The gas concentration and the emission of the gases $\mathrm{NH}_{3}, \mathrm{CH}_{4}$ and $\mathrm{CO}_{2}$ were high through summer seasons and low through winter seasons except for $\mathrm{N}_{2} \mathrm{O}$ which had low gas concentration and emission through summer seasons but high through winter seasons, owing to the 
temperature differences between summer and winter where the concentrations of the gases and their emissions increase with air temperature except for nitrous oxide that behaves in contrary.

\section{ACKNOWLEDGEMENTS}

The author would like to acknowledge the Department of Engineering for Livestock Management at the Leibniz Institute for Agricultural Engineering Potsdam-Bornim (ATB) in Germany, for the technical and logistical support during the measurements campaigns. Furthermore, the author gratefully acknowledges the assistance of the Institute for Animal Production, State Institute for Agriculture and Fishery MV, Dummerstorf, Germany.

\section{REFERENCES}

Adviento-Borbe, M. A. A., Wheeler, E. F., Brown, N. E., Topper, P. A., Graves, R. E., Ishler, V. A., \& Varga, G. A. (2010). Ammonia and greenhouse gas flux from manure in freestall barn with dairy cows on precision fed rations. Transactions of the ASABE, 53(4), 12511266.

Bjorneberg, D. L., Leytem, A. B., Westermann, D. T., Griffiths, P. R., Shao, L., \& Pollard, M. J. (2009). Measurements of atmospheric ammonia, methane, and nitrous oxide at a concentrated dairy production facility in southern Idaho using open-path FTIR spectrometry. Transactions of the ASABE, 52(5), 1749-1756.

Demmers, T. G. M., Phillips, V. R., Short, L. S., Burgess, L. R., Hoxey, R. P., \& Wathes, C. M. (2001). Validation of ventilation rate measurement methods and the ammonia emission from naturally ventilated dairy and beef buildings in the United Kingdom. Journal of Agricultural Engineering Research, 79 (1), 107-116.

FAO (2006). Livestock's role in climate change and air pollution. <ftp://ftp.fao.org/docrep/fao/010/a0701e/A0701E03.pdf> (accessed in December 2010). 
Giltrap, D. L., Singh, J., Saggar, S., \& Zaman, M. (2010). A preliminary study to model the effects of a nitrification inhibitor on nitrous oxide emissions from urine-amended pasture. Agriculture, Ecosystems and Environment, 136 (2010), 310-317.

IPCC (2007). Climate Change 2007: Mitigation. Contribution of Working Group III to the Fourth Assessment Report of the Intergovernmental Panel on Climate Change. B. Metz, O.R. Davidson, P.R. Bosch, R. Dave, L.A. Meyer (eds), Cambridge University Press, Cambridge, United Kingdom and New York, NY, USA., 841 pp.

Lung, T., Müller, H. J., Gläser, M., \& Möller, B. (2002). Measurements and modelling of full-scale concentration fluctuations: open-field experiments using krypton-85 and tetrahydrothiophene as tracers. Agrartechnische Forschung, 8(1/3), 5-15.

Madsen J., Bjerg, B.S., Hvelplund, T., Weisbjerg, M.R., \& Lund, P. (2010). Methane and carbon dioxide ratio in excreted air for quantification of the methane production from ruminants. Livestock Science, 129 (2010), 223-227.

Müller, H. J., \& Möller B. (1998). The further development of air exchange measurement techniques using tracer gases. Landtechnik, 53(5), 326-327.

Ngwabie, N. M., Jeppsson, K.-H., Nimmermark, S., Swensson, C., \& Gustafsson, G. (2009). Multi-location measurements of greenhouse gases and emission rates of methane and ammonia from a naturallyventilated barn for dairy cows. Biosystems Engineering, 103(2009), 68-77.

Pedersen, S., Blanes-Vidal, V., Joergensen, H., Chwalibog, A., Haeussermann, A., Heetkamp, M.J.W., \& Aarnink A.J.A. (2008). Carbon dioxide production in animal houses: a literature review. Agricultural Engineering International: CIGR Ejournal, Manuscript BC 08 008, Vol. X. December, 2008.

Pereira, J., Fangueiro, D., Misselbrook, T., Chadwick, D., Coutinho, J., Trindade, H. (2011). Ammonia and greenhouse gas emissions from 
slatted and solid floors in dairy cattle houses: A scale model study. Biosystems Engineering, 109(2011), 148-157.

Pinares-Patino, C. S., \& Clark, H. (2008). Reliability of the sulfur hexafluoride tracer technique for methane emission measurement from individual animals: an overview. Australian Journal of Experimental Agriculture, 48(1-2), 223-229.

Reinhardt-Hanisch, A. (2008). Grundlagenuntersuchungen zur Wirkung neuartiger Ureaseinhibitoren in der Nutztierhaltung, in German (Basic research on the effects of novel urease inhibitors in animal housing). PhD diss., University of Hohenheim, Stuttgart, Germany.

Schneider, T., Buscher, W., \& Wallenfang, O. (2005). Validation of the tracer gas method for air volume flow measurement. Landtechnik, 60(6), 344-345.

Schuurkes, J., and R. Mosello (1988). The role of external ammonium inputs in freshwater acidification. Aquatic Sciences - Research Across Boundaries, 50(1), 71-86.

Sherman, M. H. (1989). On the estimation of multizone ventilation rates from tracer gas measurements. Building and Environment, 24(4), 355-362.

Snell, H., Seipelt, F., \& van den Weghe, H. (2003). Ventilation rates and gaseous emissions from naturally ventilated dairy houses. Biosystems Engineering, 86(1), 67-73.

TA-Luft (2002). Technical instructions on air quality control. Federal Ministry for the environment, nature conservation and nuclear safety. http://www.taluft.com/taluft20020730.pdf

Xin, H., Li, H., Burns, R. T., Gates, R. S., Overhults, D. G., \& Earnest, J. W. (2009). Use of $\mathrm{CO}_{2}$ concentration difference or $\mathrm{CO}_{2}$ balance to assess ventilation rate of broiler houses. Transactions of the ASABE, 52(4), 1353-1361. 


\section{الملخص العربي

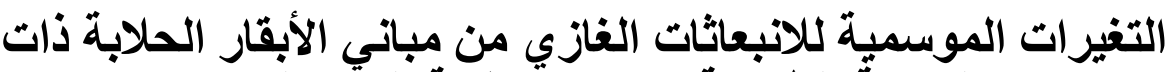

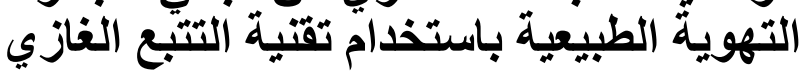 \\ محمد سـامر'}

أجريت تسعة والعشرين تجربة مبدانية لدر اسة معدل التهوية في حظيرة أبقار حلابة ذات نظام تهوية طبيعية خلال ع مو اسم صيف وب مو اسم شتاء. و وتم تحديد معدل تبادل الهو اء بو اسطة تقنية التتبع الغازي وكذلك باستخدام ميزان الكتلة لغاز ثاني أكسيد الكربون و الذي استخدم كطريقة مرجعية في التحليل الاحصائي.

خلال كل التجارب الميدانية ، تم إجر اء قياسات مستمرة للتركيز ات الغازية ( $\mathrm{CO}_{2}$ ، ( $\mathrm{N}_{2} \mathrm{O}$ ، CH 4

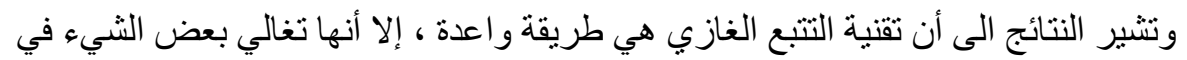

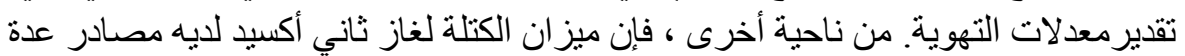

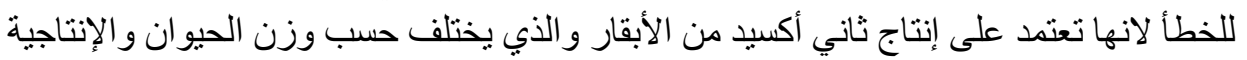
و الحمل. لذا ينبغي تطوير تقنية التبع الغازي حيث أنها توفر نتائج قريبة من ميز ان ان الكتلة لغاز ثاني أكسيد الكربون و علاوة على ذللك فهي مستقلة عن التغير ات الفسيولوجية للحيو انات.

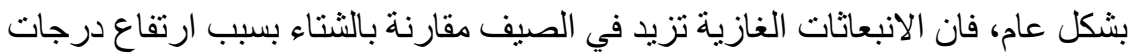

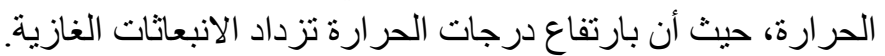

الكلمات المفتاحية:

تقنية التتبع الغازي، ميزان الكتلة لغاز ثاني أكسيد، الانبعاثات الغازية، مباني الأبقار الحلابة.

'مدرس بقسم الهندسة الزراعية، كلية الزراعة، جامعة القاهرة. rباحث بمعه لايبنيتز للهندة الزراعية، بوتسدام، ألمانيا. 